\title{
MATHEMATICAL MODEL OF TARGETS ENGAGEMENT EFFICIENCY EVALUATION BY THE DATA OF ADJUSTMENT GUN FOR JET PROJECTILES AND PROJECTILES WITH “TRANSPONDER” IN THE GPS- TRACKER SYSTEM
}

B. Popkov

The article presents a system of errors for jet (fin-stabilized) projectiles, occurring during artillery systems fire on the basis of error system analysis of range and direction of artillery systems fire for spinning projectiles. Probable errors in preparation of settings on the data of the adjustment guns for jet (fin-stabilized) projectiles, as well as projectiles equipped with "transponder" in the GPS-tracker system have been defined; probability of engagement and relative increase of target engagement probability has been calculated.

Key words: probable errors, adjustment gun, jet (fin-stabilized) projectiles, target engagement probability, GPS-tracker.

\section{УДК 623}

П.О. Русіло, Р.Г. Будяну, О.М. Калінін, В.В. Костюк, Ю.В. Варванець

Академія сухопутних військ імені гетьмана Петра Сагайдачного

\section{ОБГРУНТУВАННЯ ТАКТИКО-ТЕХНІЧНИХ ХАРАКТЕРИСТИК ДЛЯ РОЗРОБЛЕННЯ ПЕРСПЕКТИВНИХ ЗРАЗКІВ І ПОДАЛЬШОЇ МОДЕРНІЗАЦЇ ВІТЧИЗНЯНИХ БРОНЕТРАНСПОРТЕРІВ}

Проведена оцінка рівня технічної досконалості найкращих сучасних зразків бронетранспортерів з колісною формулою $8 \times 8$, яка обтрунтовує тактико-технічні характеристики для модернізаиії та розроблення перспективних зразків. Порівняльний аналіз рівня технічної досконалості свідчить про те, що вітчизняні бронетранспортери БТР-4 «Ладья» і БТР-3Е1 займають провідне місие серед перспективних зразків, які знаходяться в серійному виробництві і на озброєні армій передових країн світу.

Ключові слова: базове шасі, бронетранспортер, зразок, модернізачія, рівень технічної досконалості, тактико-технічні характеристики.

\section{Вступ}

Постановка проблеми. Досвід ведення бойових дій у сучасних збройних конфліктах показуе, що для успішного виконання бойових завдань механізованих i танкових підрозділів, забезпечення необхідного рівня мобільності підрозділів та захисту особового складу ефективно використовуються броньовані машини.

Бронетранспортер (БТР) як броньована колісна або гусенична машина підвищеної прохідності може використовуватися в ході проведення миротворчих операцій для бойової охорони військ, несення служби на блокпостах, супроводження колон, патрулювання конфліктних зон, проведення асиметричних автономних дій у відповідь противнику [1]. Спеціально обладнані БТР використовуються для доставки на поле бою зброї, боєприпасів та іншого військового майна, евакуацію поранених. Стрімкий розвиток засобів збройної боротьби, тактики ведення бою i нових організаційно-штатних структур збройних формувань постійно вносить свої корективи до вимог, які висуваються до сучасної і перспективної бронетанкової техніки.

Обгрунтування тактико-технічних характеристик для розроблення нових перспективних зразків $\mathrm{i}$ подальшої модернізації вітчизняних бронетранспортерів $\epsilon$ актуальним.

\section{Аналіз останніх досліджень і публікацій}

Досвід бойового застосування БТР у локальних конфліктах в останні десятиріччя підтвердив крайню необхідність мати машини 3 підвищеним рівнем основних бойових характеристик.

На сьогодні практично в усіх арміях світу основну частку бронетанкового озброєння та техніки складають бойові колісні машини типу БТР.

Поряд 3 ефективним використанням існуючих зразків БТР одночасно відбувається процес модернізації та розроблення нових і перспективних [2-11].

Одним з головних напрямів, які розвиваються на світовому ринку бойових броньованих машин в останні роки $\epsilon$ проектування, розроблення $\mathrm{i}$ закупівля БТР з колісною формулою $8 \times 8$. 
Аналізуючи перспективний розвиток створення нового покоління БТР у провідних країнах світу, можна виділити головні конструктивні особливості:

- в конструкції і комплектації БТР передбачене розміщення сучасних засобів розвідки та ураження;

- удосконалення бронетанкового озброєння i техніки базується на підставі модульних компонувальних рішень, автоматизації процесів управління вогнем, захистом i рухомістю, підвищення живучості та автономності, поліпшення ергономіки, впровадження в конструкцію зразків БТР елементів штучного інтелекту.

Аналіз сучасного розвитку бронетанкової техніки свідчить про те, що у світі існує дві тенденції розвитку бронетранспортерів:

- розроблення і створення нових зразків БТР;

- модернізація раніше випущених зразків БТР, які знаходяться на озброєнні та виробництві.

Перспективний розвиток створення БТР має характерні особливості:

- застосування максимальної уніфікації БТР 3 модульним виконанням основних складових частин машини (корпуса i шасі) дозволяє на одному шасі створити декілька машин абсолютно різного призначення, що вже давно виправдовує себе як 3 економічної, так і експлуатаційної точки зору;

- комплектування БТР сучасними система озброєння і захисту, автоматизованими системами бойової взаємодії, єдиним комплексом бортової електроніки, новими способами управління озброєнням (зовнішнє цілевказання, автоматичне супроводження цілей, дистанційне керуванням вогнем i підривання боєприпасів), а також тепловізорами і радіолокаційними станціями.

Основною метою модернізації БТР $є$ його адаптація до сучасних умов ведення бойових дій. Все частіше на нього покладаються функції БМП щодо ураження броньованих цілей та живої сили противника. Конструкція і компоновка складових частин повинна перетворити БТР у броньовану високо захищену бойову машину 3 потужними системами озброєння. Висока рухомість i маневреність у поєднанні з потужними вогневими можливостями, комфортабельним розташуванням екіпажу і десанту повинні зробити БТР зручними під час виконання бойових завдань. Це вимагає комплексного підходу під час обгрунтування оперативно-тактичних вимог до сучасних зразків БТР. Крім вогневої потужності, захищеності, рухомості, командної керованості і живучості у цілому, виникає необхідність підвищення рівня технічної досконалості (окремих тактико-технічних характеристик) зразків БТР. У публікаціях відсутній порівняльний аналіз тактико-технічних характеристик сучасних існуючих і перспективних БТР, які модернізуються або розробляються, не висловлюється думка стосовно кращого або гіршого зразка БТР.

\section{Формування мети статті}

$\begin{array}{ccccc}\text { Сьогодні } & \text { Збройні } & \text { Сили } & \text { України } & \text { оснащені } \\ \text { декількома } & \text { типами } & \text { БТР } & 3 & \text { різними }\end{array}$ функціональними призначеннями. Враховуючи особливості їхнього застосування в сучасних бойових діях, бронетранспортери повинні бути уніфіковані на базовому шасі єдиної колісної платформи, яка має достатній запас корисного навантаження. 3 метою обгрунтування тактикотехнічних характеристик для модернізації існуючих і розроблення перспективних уніфікованих зразків БТР ЗС України проведено порівняльний аналіз найбільш прийнятних типів сучасних бронетранспортерів провідних країн світу, визначені слабкі і сильні їхні сторони, рекомендовані раціональні напрями удосконалення рівня технічної досконалості.

\section{Виклад основного матеріалу}

Через велику номенклатуру існуючих i перспективних зразків БТР постає питання необхідності визначення їхього відносного рівня технічної досконалості для подальшого вибору напрямів удосконалення вітчизняних зразків. Для порівняльної оцінки тактико-технічних характеристик зразків БТР 3 колісною формулою $8 \times 8$ попередньо було розглянуто 14 машин, які знаходяться в серійному виробництві і на озброєні армій передових країн світу. Порівняльний аналіз переваг i недоліків, їхнє широке застосування i подальше використання дають змогу виокремити 9 зразків БТР, які за рівнем технічної досконалості на перший погляд не дуже сильно різняться (табл. 1).

Оскільки технічні i тактико-технічні характеристики зазначених БТР виражені у різних одиницях вимірювання, то їхні значення доцільно нормувати за допомогою рангової шкали вимірювання [12]. Якщо найбільше значення показника покращує технічну досконалість БТР, то йому надається (присвоюється ранг) найбільша оцінка 10, а якщо погіршує - найменша оцінка 1. У разі однакових значень показника у декількох зразків БТР, необхідно суму місць, які вони посідають за порядком в ряді рангів, поділити на їх кількість. Сума оцінок за рангами є комплексним показником оцінки рівня технічної досконалості однотипних зразків ОВТ (табл. 2).

Максимальне значення комплексного показника рівня технічної досконалості зразка становить 9×7=63 (балів). Зразка БТР, який би набрав таку суму (мав всі найкращі значення показників), не існує. Отже всі розглянуті зразки БТР мають право на подальше удосконалення. 
Тактико-технічні характеристики однотипних зразків БТР

\begin{tabular}{|c|l|c|c|c|c|c|c|c|}
\hline $\begin{array}{c}\text { № } \\
\text { з/п }\end{array}$ & \multicolumn{1}{|c|}{$\begin{array}{c}\text { Зразок } \\
\text { БТР }\end{array}$} & $\begin{array}{c}\text { Бойова } \\
\text { маса, кг }\end{array}$ & $\begin{array}{c}\text { Потужність } \\
\text { двигуна, к. с. }\end{array}$ & $\begin{array}{c}\text { Запас ходу, } \\
\text { км }\end{array}$ & $\begin{array}{c}\text { Макс. швидк., } \\
\text { км/год. }\end{array}$ & $\begin{array}{c}\text { Довжина, } \\
\text { м }\end{array}$ & $\begin{array}{c}\text { Ширина, } \\
\text { м }\end{array}$ & $\begin{array}{c}\text { Висота, } \\
\text { м }\end{array}$ \\
\hline 1 & $\begin{array}{l}\text { БТР-4 (Україна, } \\
\text { 2008) }\end{array}$ & 17500 & 500 & 690 & 110 & 7,65 & 2,9 & $\begin{array}{c}3,06 \\
\text { (мод. Парус) }\end{array}$ \\
\hline 2 & $\begin{array}{l}\text { БТР-3Е1 } \\
\text { (Україна, 2011) }\end{array}$ & 16500 & 326 & 600 & 100 & 7,85 & 2,9 & 2,77 \\
\hline 3 & $\begin{array}{l}\text { Stryker M1126 } \\
\text { (США, 2003) }\end{array}$ & 19000 & 350 & 530 & 97 & 6,95 & 2,72 & 2,84 \\
\hline 4 & $\begin{array}{l}\text { Рandur II } \\
\text { (Австрія, 2007) }\end{array}$ & 22000 & 455 & 700 & 105 & 7,63 & 2,67 & 2,85 \\
\hline 5 & $\begin{array}{l}\text { LАV III Коdiak } \\
\text { (Канада, 1999) }\end{array}$ & 16950 & 350 & 500 & 100 & 6,934 & 2,667 & 2,8 \\
\hline 6 & $\begin{array}{l}\text { VВМ Frecсіа } \\
\text { (Італія, 2006) }\end{array}$ & 26000 & 550 & 800 & 110 & 8,6 & 2,9 & 3,0 \\
\hline 7 & $\begin{array}{l}\text { GТК Вохег } \\
\text { (ФРН, 2009) }\end{array}$ & 33000 & 720 & 1050 & 103 & 7,93 & 2,99 & 2,37 \\
\hline 8 & $\begin{array}{l}\text { Туре-09 ZВL-09 } \\
\text { (Китай, 2009) }\end{array}$ & 21000 & 440 & 800 & 100 & 8,0 & 3,0 & 2,1 \\
\hline 9 & $\begin{array}{l}\text { АМV Рatria } \\
\text { (Фінляндія, 2004) }\end{array}$ & 16000 & 490 & 800 & 100 & 7,7 & 2,8 & 2,3 \\
\hline
\end{tabular}

Таблиия 2

Рангова оцінка тактико-технічної характеристики однотипних зразків БТР

\begin{tabular}{|c|l|c|c|c|c|c|c|c|c|}
\hline $\begin{array}{c}\text { №3/ } \\
\text { п }\end{array}$ & Зразок БТР & $\begin{array}{c}\text { Бойова } \\
\text { маса, кг }\end{array}$ & $\begin{array}{c}\text { Потужність } \\
\text { двигуна, к. с. }\end{array}$ & $\begin{array}{c}\text { Запас ходу, } \\
\text { км }\end{array}$ & $\begin{array}{c}\text { Макс. швидк., } \\
\text { км/год. }\end{array}$ & $\begin{array}{c}\text { Довжина, } \\
\text { м }\end{array}$ & $\begin{array}{c}\text { Ширина, } \\
\text { м }\end{array}$ & $\begin{array}{c}\text { Висота, } \\
\text { м }\end{array}$ & \begin{tabular}{c} 
Сума \\
\hline 1
\end{tabular} \\
\hline БТР-4 & 6 & 7 & 4 & 8,5 & 6 & 4 & 1 & 36,5 \\
\hline 2 & БТP-3Е1 & 8 & 1 & 3 & 5 & 4 & 4 & 6 & 31 \\
\hline 3 & Stryker M1126 & 5 & 2,5 & 2 & 1 & 8 & 7 & 5 & 30,5 \\
\hline 4 & Pandur II & 3 & 5 & 5 & 7 & 7 & 8,5 & 4 & 39,6 \\
\hline 5 & LAV III Kodiak & 7 & 2,5 & 1 & 3,5 & 9 & 8,5 & 3 & 34,5 \\
\hline 6 & VBM Freccia & 2 & 8 & 7 & 8,5 & 1 & 4 & 2 & 32,5 \\
\hline 7 & GTK Boxer & 1 & 9 & 9 & 6 & 3 & 2 & 7 & 37 \\
\hline 8 & Type-09 ZBL-09 & 4 & 4 & 7 & 3,5 & 2 & 1 & 9 & 30,5 \\
\hline 9 & AMV Patria & 9 & 6 & 7 & 3,5 & 5 & 6 & 8 & 44,5 \\
\hline
\end{tabular}

За даними табл. 2 побудовані профілі рівня технічної досконалості зразків БТР. Аналіз профілів дозволяє відмітити слабкі і сильні показники тактико-технічних характеристик зразків, намітити напрямки удосконалення рівня технічної досконалості зразка БТР, тобто визначити показники, які потребують покращення тактикотехнічних характеристик [13]. Наприклад: для зразка БТР-4 треба покращити показник 3 збільшити запас ходу і особливо показник 7 зменшити висоту; для зразка БТР $3 \mathrm{E}-1$ особливе значення має підвищення потужності двигуна i збільшення запасу ходу; зразок GTK Boxer потребує покращення показників 1, 5, 6 - зменшення маси, довжини і ширини. Найкраще співвідношення між показниками тактико-технічних характеристик мають зразки БТР AMV Patria, і особливо Pandyr II однак i вони потребують покращення деяких тактико-технічних характеристик.

Рангова шкала вимірювання не визначає інтервал оцінювання між досліджуваними зразками
БТР, а лише дозволяє визначити характер нерівності у вигляді міркувань: більше, менше, краще, гірше, тому іiі доцільно використовувати лише для вибору напрямів удосконалення рівня технічної досконалості однотипних зразків озброєння та військової техніки. Оцінювання рівня технічної досконалості однотипних зразків БТР було виконано за допомогою шкали оцінок [14]. Таке оцінювання дозволяє підвищити точність значення комплексного показника рівня технічної досконалості і визначити на скільки балів один зразок кращий (гірший) відносно інших.

Оцінку в балах технічних і тактико-технічних характеристик зразків знаходять за пропорційною шкалою оцінок (табл. 3).

Для показників, які покращують рівень технічної досконалості, за формулою

$$
O_{\text {бал. }}=\left(\frac{X_{\text {очін. }}-X_{\text {мін. }}}{X_{\text {макс. }}-X_{\text {мін. }}}\right) \times 100 \text { балів. }
$$



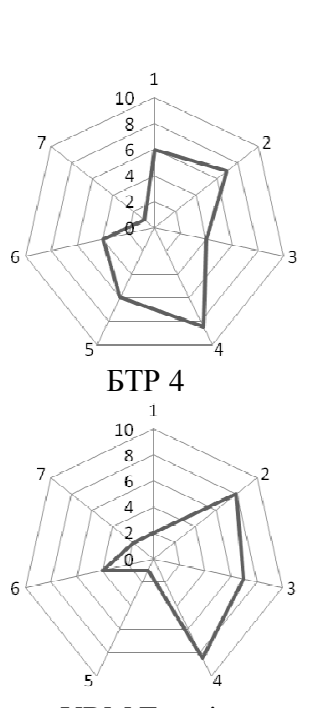

VBM Freccia

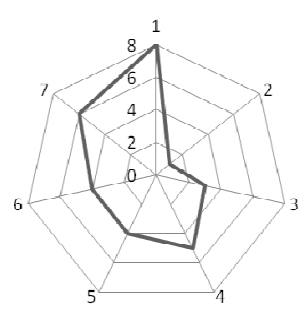

БТР -3E1

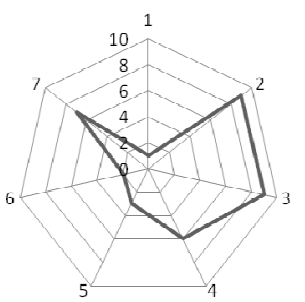

GTK Boxer

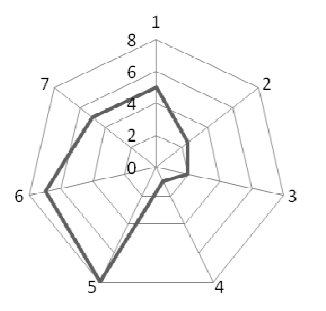

Stryker M1126

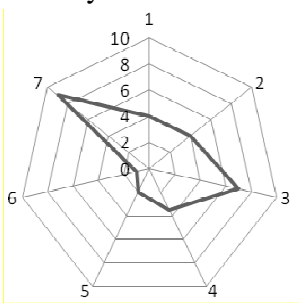

Type-09

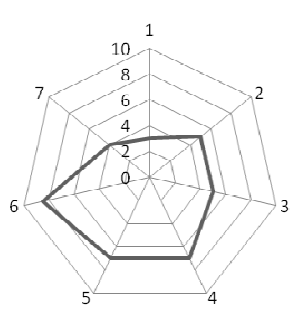

Pandyr II

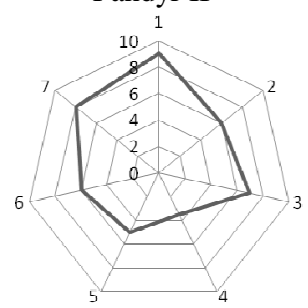

AMV Patria

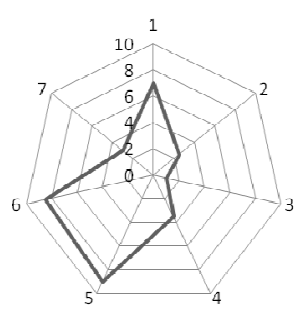

LAV III Kodiak

Рис. 1. Профілі рівня технічної досконалості зразків БТР:

1 - бойова маса, 2 - потужність двигуна, 3 - запас ходу, 4 - максимальна швидкість, 5 - довжина, 6 - ширина, 7 - висота

Оцінка для показників, які погіршують рівень технічної досконалості, за формулою

$$
O_{\text {бал. }}=\left(\frac{X_{\text {мах. }}-X_{\text {оиін. }}}{X_{\text {макс. }}-X_{\text {мін. }}}\right) \times 100 \text { балів, }
$$

де $\mathrm{X}_{\text {оцін. }}, \mathrm{X}_{\text {макс. }} \mathrm{i} \mathrm{X}_{\text {мін. }}$ - оцінююче, максимальне $\mathrm{i}$ мінімальне значення показника у групі однотипних зразків, відповідно.
Оцінка рівня технічної досконалості за пропорційною шкалою вимірювання не враховує вагомість кожної технічної і тактико-технічної характеристики, що суттєво може відобразитися на кінцевому результаті. В якості комплексного показника рівня технічної досконалості вибрали суму добутків оцінок показників технічних i тактико-технічних характеристик однотипних зразків ОВТ, які визначені за пропорційною шкалою вимірювання, на їхній коефіцієнт вагомості $\mathrm{K}_{\mathrm{B}}$.

Таблиия 3

Оцінка тактико-технічних характеристик однотипних зразків БТР за пропорційною шкалою вимірювання

\begin{tabular}{|c|c|c|c|c|c|c|c|c|c|}
\hline №3/ח & Зразок БТР & $\begin{array}{c}\text { Бойова } \\
\text { маса, кг }\end{array}$ & $\begin{array}{l}\text { Потужність } \\
\text { Двигуна, к. с }\end{array}$ & $\begin{array}{c}\text { Запас ходу, } \\
\text { км }\end{array}$ & $\begin{array}{c}\text { Макс. швидк., } \\
\text { км/год. }\end{array}$ & \begin{tabular}{|c|} 
Довжина, \\
м
\end{tabular} & $\begin{array}{c}\text { Ширина, } \\
\text { м }\end{array}$ & $\begin{array}{c}\text { Висота, } \\
\text { м }\end{array}$ & Сума \\
\hline 1 & БТР-4 & 91,2 & 36,5 & 34,5 & 100,0 & 57,0 & 30,0 & 0 & 349,2 \\
\hline 2 & БТР-3E1 & 97,1 & 0 & 18,2 & 23,1 & 45,0 & 30,0 & 30,0 & 243,4 \\
\hline 3 & Stryker M1126 & 82,4 & 6,1 & 5,5 & 0 & 99,0 & 84,1 & 23,0 & 300,1 \\
\hline 4 & Pandur II & 64,7 & 32,7 & 36,4 & 61,5 & 58,0 & 99,1 & 21,9 & 374,3 \\
\hline 5 & LAV III Kodiak & 94,4 & 6,1 & 0 & 23,1 & 100,0 & 100,0 & 27,1 & 350,7 \\
\hline 6 & VBM Freccia & 41,2 & 56,9 & 54,5 & 100,0 & 0 & 30,0 & 6,3 & 288,9 \\
\hline 7 & GTK Boxer & 0 & 100,0 & 100,0 & 46,2 & 40,0 & 3,0 & $71,9,0$ & 289,2 \\
\hline 8 & Type-09 ZBL-09 & 70,6 & 28,9 & 54,5 & 23,1 & 36,0 & 0 & 100,0 & 313,1 \\
\hline 9 & AMV Patria & 100,0 & 41,6 & 54,5 & 23,1 & 54,0 & 60,1 & 79,2 & 412,5 \\
\hline
\end{tabular}

Для обгрунтування вагових коефіцієнтів окремих тактико-технічних характеристик нами використаний метод експертних оцінок (табл. 4). Використання цього методу передбачає залучення до оцінювання вагових коефіцієнтів провідних науковців, практиків, експертів 3 проблеми оцінювання рівня технічної досконалості зразків
OBT. Ступінь узгодженості думок експертів визначався за величиною коефіцієнта конкордації. Значення коефіцієнта конкордації залежно від характеристики було в межах від 0,80 до 0,88 , що вказує на середню надійність узгодженості експертів [15]. 
Оцінка тактико-технічної характеристики однотипних зразків БТР за сумарною шкалою вимірювання: оцінкахвагомість

\begin{tabular}{|c|c|c|c|c|c|c|c|c|c|}
\hline №3/ா & Зразок БТР & $\begin{array}{l}\text { Бойова } \\
\text { маса, кг }\end{array}$ & $\begin{array}{l}\text { Потужність } \\
\text { двигуна, к. с. }\end{array}$ & $\begin{array}{c}\text { Запас ходу, } \\
\text { км }\end{array}$ & $\begin{array}{c}\text { Макс. швидк., } \\
\text { км/год. } \\
\end{array}$ & \begin{tabular}{|c} 
Довжина, \\
м
\end{tabular} & \begin{tabular}{|c|}
\begin{tabular}{|} 
Ширина, \\
м
\end{tabular} \\
\end{tabular} & \begin{tabular}{|c|}
$\begin{array}{c}\text { Висота, } \\
\text { м }\end{array}$ \\
\end{tabular} & Сума \\
\hline 1 & БТР-4 & 10,94 & 10,95 & 5,52 & 18 & 4,00 & 2,40 & 0 & 51,81 \\
\hline 2 & БТР-3E1 & 11,65 & 0 & 2,91 & 4,16 & 3,16 & 2,40 & 2,7 & 26,98 \\
\hline 3 & Stryker M1126 & 9,89 & 1,83 & 0,88 & 0 & 6,96 & 6,73 & 2,1 & 28,39 \\
\hline 4 & Pandur II & 7,76 & 9,81 & 5,82 & 11,07 & 4,09 & 7,93 & 2,0 & 48,48 \\
\hline 5 & LAV III Kodiak & 11,33 & 1,83 & 0 & 4,16 & 7,00 & 8,00 & 2,4 & 34,72 \\
\hline 6 & VBM Freccia & 4,94 & 17,07 & 8,72 & 18 & 0 & 2,40 & 0,6 & 51,73 \\
\hline 7 & GTK Boxer & 0 & 30 & 16 & 8,32 & 2,83 & 0,24 & 6,5 & 63,89 \\
\hline 8 & Type-09 ZBL-09 & 8,47 & 8,67 & 8,72 & 4,16 & 2,53 & 0 & 9,0 & 41,55 \\
\hline \multirow[t]{2}{*}{9} & AMV Patria & 12 & 12,48 & 8,72 & 4,16 & 3,79 & 4,81 & 7,2 & 53,16 \\
\hline & $\mathrm{K}_{\mathrm{B}}$ & 0,12 & 0,30 & 0,16 & 0,18 & 0,07 & 0,08 & 0,09 & 1,0 \\
\hline
\end{tabular}

Вітчизняний БТР-4Е „Ладья” за своїми тактико-технічними характеристиками та експлуатаційними властивостями належить до трійки найкращих сучасних зразків БТР, що відповідають сучасним світовим тенденціям розвитку бойових броньованих машин (рис. 2 і 3 ). Він має колісну формулу $8 \times 8$, принципово нову компоновку 3 трьома відділеннями (управління, силова установка та трансмісія, бойове та десантне) i на $100 \%$ виготовляється та оснащується вітчизняними комплектуючими виробами та озброєнням. Машина має модульну конструкцію i високий рівень балістичного і протимінного захисту на рівні 2 STANAG-4269. Озброєння бронетранспортера складається 3 бойового модуля „Парус”, обладнаного 30-мм гарматою з спареним 3 нею кулеметом, 30-мм автоматичним гранатометом, протитанковим ракетним комплексом, які об'єднані в єдину систему керування вогнем.

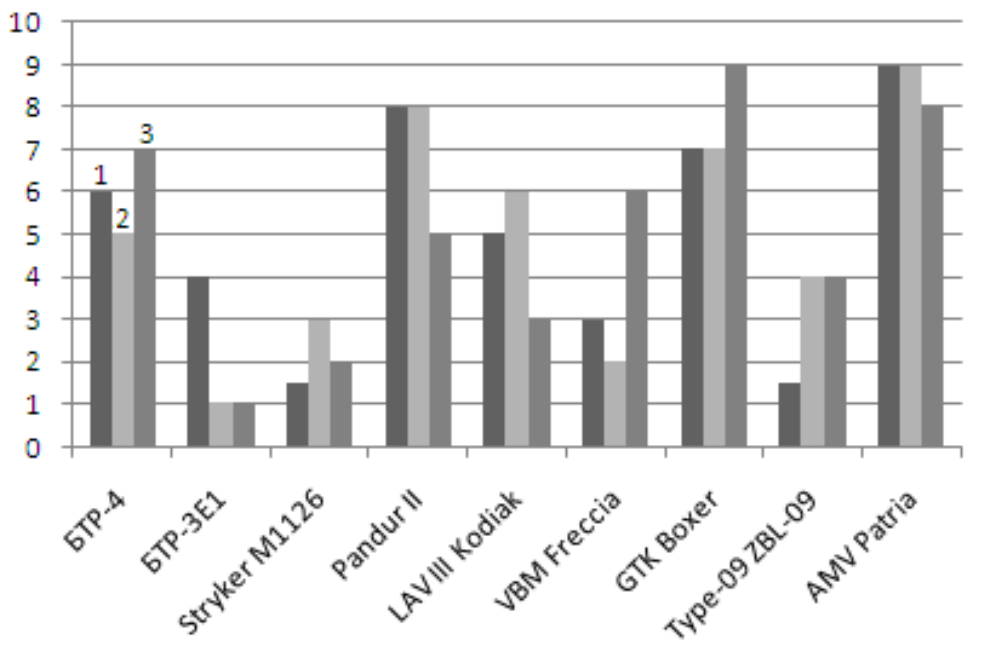

Рис. 2. Оцінка рівня технічної досконалості однотипних зразків БТР за шкалами вимірювань 3 урахуванням семи показників: шкали: рангова -1 , оцінок -2 , оцінкахвагомість -3

На базі бронетранспортера БТР-4Е „Ладья” у подальшому може бути створено низку (сімейство) машин різного призначення: колісна бойова машина піхоти, командирська машина, бойова розвідувальна машина, броньована командно-штабна машина, машина вогневої підтримки (з гарматою калібром до 120 мм), броньована ремонтно-евакуаційна машина, броньована санітарна машина та інші.

Ефективність бойового використання колісної броньованої машини безпосередньо залежить від основних тактико-технічних характеристик: бойової маси, потужності силової установки, запасу ходу, динамічності, захищеності та вогневою потужності (рис. 3). Саме на таких показниках була зосереджена основна увага фахівці під час розроблення БТР-3Е1. За базову модель взято шасі БТР-80, що дозволило скоротити час випуску нової машини, використовувати вітчизняні комплектуючі i зберегти наявну систему підготовки механіків-водіїв та екіпажів машин. 


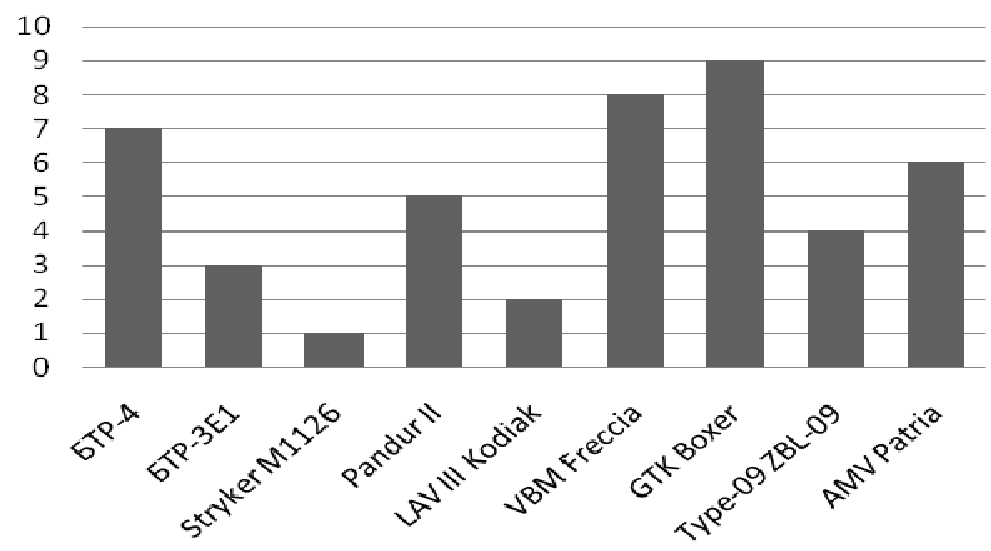

Рис. 3. Оцінка рівня технічної досконалості зразків БТР за сумою перших чотирьох показників з урахуванням вагомості за сумою балів:

бойова маса, потужність двигуна, запас ходу і максимальна швидкість

Для посилення вогневої потужності на БТР-3Е1 встановлено вітчизняну 30-міліметрову автоматичну гармату і спарений з нею кулемет. На башті бронетранспортера встановлено дві установки для протитанкових керованих ракет «Комбат» і 30-міліметровий автоматичний гранатомет. Бойовий модуль вітчизняного бронетранспортера укомплектований чотирма видами зброї для ураження броньованої техніки, гелікоптерів $\mathrm{i}$ живої сили противника. У процесі подальшої модернізації на БТР-3Е1 встановлені сучасні засоби прицілювання для забезпечення можливості вести вогонь уночі, система панорамного огляду, яка дозволяє членам екіпажу тримати у полі зору місцевість під розгорнутим кутом (практично 360 градусів). Для підвищення захищеності конструкції цієї бронемашини внутрішню частину броні покрито кевларом із спеціальною системою кріплення. Значно підвищені швидкісні та динамічні якості БТР-3Е1 встановленням двигуна українського виробництва УТД-20 3 оригінальною системою охолодження ежекційного типу, яка здатна забезпечити безперебійну роботу двигуна в умовах підвищеної температури навколишнього повітря до $+50^{\circ} \mathrm{C}$. Також передбачена можливість встановлення на машині двигунів іноземного виробництва «Deutz» або «Mercedes» із автоматичною коробкою передач.

На вітчизняних БТР впроваджуються заходи щодо забезпечення надійної роботи силової установки $\mathrm{i}$ значного спрощення обслуговування та ремонту іiі складових частин. Одночасно з серійним виробництвом цих БТР для практичного відпрацювання навичок членами екіпажу передбачено випуск тренажерних комплексів, які повністю моделюють рух бойової машини. Машини забезпечуються запасними частинами, деталями та витратними матеріалами, які необхідні для безперебійної експлуатації машин протягом тривалого часу.

\section{Висновки}

1. Дослідження рівня технічної досконалості однотипних зразків БТР за даними тактико-технічних характеристик з Інтернет-сайтів показують що:
- вітчизняні бронетранспортери БТР-4 «Ладья» і БТР-3Е1 за комплексним показником оцінки рівня технічної досконалості входять в дев'ятку кращих зразків БТР із 14 перспективних, які знаходяться на озброєнні в арміях передових країн світу.

- найбільш надійними в експлуатації та перспективними у подальшій модернізації вважаються зразки GTK Boxer (ФРН, 2009), AMV Patria (Фінляндія, 2004) і БТР-4 «Ладья» (Україна, 2008);

- значно поступаються за основними чотирма показниками 3 урахуванням вагомості зразки LAV III Kodiak (Канада, 1999) i Stryker M1126(США, 2003).

2. Крім високих тактико-технічних характеристик, кращі сучасні зразки БТР характеризуються високою мобільністю, рухомістю, захищеністю та вогневою потужністю, а також комплексом 3 автоматизованою системою бойової взаємодії.

3. Особливістю вітчизняного БТР-3Е1 $є$ його виготовлення 3 вітчизняних комплектуючих, що забезпечує скорочення часу та матеріальних витрат на його випуск і зберігає напрацьовану систему підготовки механіків-водіїв та екіпажів.

4. На базі сучасного вітчизняного зразка БТР-4 «Ладья» доцільно розробити низку (сімейство) типових уніфікованих броньованих колісних шасі з підвищеною потужністю двигуна під монтаж озброєння i спеціального обладнання, а також машин різного призначення для всіх видів та родів військ. Такий підхід сприятиме суттєвому підвищенню ефективності озброєння Збройних Сил України, але лише за умов цілеспрямованого виділення коштів в рамках Державної програми розвитку озброєння та військової техніки, із залученням всіх зацікавлених управлінь і відомств Міністерства оборони, Міністерства промислової політики України та Генерального штабу ЗС України.

5. У порівнянні рівнів технічної досконалості однотипних зразків БТР, потрібно звернути увагу на те, що у процесі вивчення технічної інформації з Інтернетсайтів $є$ суттєві протиріччя у деяких показниках тактикотехнічних характеристик окремих зразків, і це може 
хибно вплинути на об'єктивне визначення реаармии и флота. - 2012. - №1.

оцінки.

6. Запропонований підхід оцінки рівня технічної досконалості однотипних зразків БТР може бути використаний військовим фахівцями-розробниками перспективних БТР за умови достовірної інформації показників тактико-технічних характеристик.

7. У подальшому для підвищення оцінки рівня технічної досконалості однотипних зразків БТР доцільно розробити комплексний показник 3 урахуванням захищеності та бойової потужності.

\section{Список літератури}

1. Кучумов С. Взгляды военного руководства США на применение Сухопутных войск / С. Кучуков // Зарубежное военное обозрение. - 2009. - №1. - С. 32-33.

2. Федосеев С. Отечественные боевые машины пехоты. История возникновения БМП / С. Федосеев // Техника и вооружение. - 2001. - №4. - С. 1-4.

3. Изюмов Д. Некоторые бронетранспортеры $и$ бронеавтомобили зарубежных стран / Д. Изюмов // Зарубежное военное обозрение. - 20011. - №3. - C. 41-43.

4. Никольский М., Ильин В. БТР-90 «Росток» / М. Никольский, В. Ильин // Техника и вооружение. - 1999. № 11-12. - С.

5. Барятинский M. Отечественные колесные броне транспортеры БТР-60, БТР-70, БТР-80 / М. Барятинский Москва: Моделист-конструктор, 2007. - С. 42-64. - (Бронеколлекция, спецвыпуск № 11).

6. http://ru.wikipedia.org/wiki/GTK Boxer.

7.http://btvt.narod/ru/4/fuchs/htm.

8. Суворов С. Финский прорыв / С. Суворов // Обозрение
9. http/morozov/com/ua/rus/body/btr4/php.

10. http://www.morozov.com.ua/rus/body/btr3u.php.

11. Василенко О.В. Основні світові тенденції розвитку озброєння та військової техніки для ведення війн у майбутньому / О.В. Василенко // Наука і оборона. - 2009. №4. - C. $18-23$.

12. Патент на корисну модель № 65254 Украӥни, МПК G01 N27/27. Спосіб очінювання рівня технічної досконалості однотипних зразків озброєння $i$ військової техніки / Ю.В. Варванець, О.М. Калінін, П.О. Русіло, М.В. Чорний; заявник та патентовласник: Академія сухопутних військ, опубл. 25.11.11. Бюл. №22, 2011 р.).

13. Патент на корисну модель № 72694 України, МПК G01 N27/27. Спосіб вибору напрямків удосконалення рівня технічної досконалості однотипних зразків озброєння та військової техніки / Ю.В. Варванець, О.М. Калінін, О.М. Купріненко, П.О. Русіло, М.В. Чорний; заявник та патентовласник: Академія сухопутних військ, опубл. 27.08.12. Бюл. №16, 2012 р.).

14. Патент на корисну модель № 72693 України, МПК G01 N27/27. Спосіб очінки рівня технічної досконалості однотипних зразків озброєння $i$ військової техніки / П.О. Русіло; заявник та патентовласник: Академія сухопутних військ, опубл. 27.08.12. Бюл. №16, 2012 р.

15. Русіло П.О. Спортивна метрологія. Основи теорії спортивних тестів і оиінок / Русіло П.О., Заневський І.П, Ярошко С.А. - Львів: ВВП ДУ «Львівська політехніка», 1995. $64 \mathrm{c.}$

Рецензент: к.т.н., доц. В.М. Зіркевич, Академія сухопутних військ імені гетьмана Петра Сагайдачного. м. Львів.

\title{
ОБОСНОВАНИЕ ТАКТИКО-ТЕХНИЧЕСКИХ ХАРАКТЕРИСТИК ДЛЯ РАЗРАБОТКИ ПЕРСПЕКТИВНЫХ ОБРАЗЦОВ И ПОСЛЕДУЮЩЕЙ МОДЕРНИЗАЦИИ ОТЕЧЕСТВЕННЫХ БРОНЕТРАНСПОРТЕРОВ
}

\author{
П.А. Русило, Р.Г. Будяну, А.М. Калинин, В.В. Костюк, Ю.В. Варванец
}

Проведена оценка уровня технического совершенства наилучших современных образиов бронетранспортеров с колесной формулой 8×8, которая обосновывает тактико-технические характеристики для модернизации и разработки перспективных образиов. Сравнительный анализ уровня технического совершенства свидетельствует о том, что отечественные бронетранспортеры БТР-4 «Ладья» и БТР-3Е1 занимают ведущее место среди перспективных образиов, которые находятся в серийном производстве и на вооруженнии армий передовых стран мира.

Ключевые слова: базовое шасси, бронетранспортер, образеи, модернизация, уровень технического совершенства, тактико-технические характеристики.

\section{GROUND OF TАКТИКО-TЕХНИЧЕСКИХ DESCRIPTIONS FOR DEVELOPMENT OF PERSPECTIVE STANDARDS AND SUBSEQUENT MODERNIZATION OF THE DOMESTIC ARMOURED TROOP-CARRIERS}

\author{
P. Rusilo, R. Budianu, A. Kalinin, V. Kostiuk, Yu. Varvanets
}

The estimation of level of technical perfection of the best modern standards of the armoured troop-carriers is conducted by the wheeled formula $8 \times 8$, which grounds тактико-технісні descriptions for modernization and development of perspective standards. The comparative analysis of level of technical perfection testifies that the domestic armoured troop-carriers of BTR-4 «Rook» and BTR-3E1 occupy a leading place among perspective standards which are in a mass production and on the armed armies of front-rank countries of the world.

Key words: base undercarriage, armoured troop-carrier, standard, modernization, level of technical perfection, тактикотехнические descriptions. 